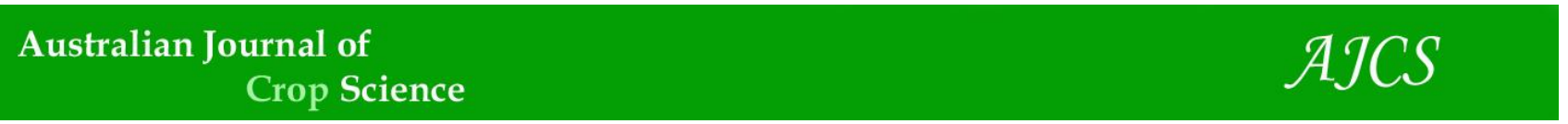

AJCS 14(06):1019-1023 (2020)

ISSN:1835-2707

doi: 10.21475/ajcs.20.14.06.p2534

\title{
Determination of raw biomass, yield and income from intercropping models of coffee (Coffea canephora Pierre) compare with perennial trees in tropical climate
}

\author{
Phan Van Tan*, Huynh Van Quoc and Dang Thi Thuy Kieu \\ Agriculture and forestry faculty, Taynguyen Uni., Buonmathuot city, Daklak province, Vietnam
}

*Corresponding author: phvtan56@gmail.com

Abstract

This is the first report of evaluation of 4 Robusta coffee intercropping models (Coffea canephora Pierre var. Robusta) with perennial trees (Siamese cassia and durian) on Rhodic ferrasol soil and tropical climate. The models were: T0 - sole coffee, T1 - intercrop of coffee with Siamese cassia (Cassia siamea Lam.), T2 - intercrop of coffee with durian (Durio zibethinus Murr.) at $9 \times 9 \mathrm{~m}$ distance and T3 - intercrop of coffee with durian at $9 \times 6 \mathrm{~m}$ distance. The results showed that the raw biomass increased from 71.6 tons ha ${ }^{-1}$ (T0) to 101.4 tons ha ${ }^{-1}$ (T1) or to 176.4 tons $\mathrm{ha}^{-1}$ (T2) or to 178.6 tons ha ${ }^{-1}$ (T3). The yield of dry coffee beans in T2 model was reduced by $300 \mathrm{~kg} \mathrm{ha}^{-1}$ and by 1,000 kg ha ${ }^{-1}$ in T3 model, respectively, compared with T0 $\left(4,120 \mathrm{~kg} \cdot \mathrm{ha}^{-1}\right)$. However, they are in the same level with T1 $\left(4,202 \mathrm{~kg} \mathrm{ha}^{-1}\right)$. The T2 and T3 models produced 22 and 23 tons ha ${ }^{-1}$ of durian fruits, respectively. Currently, planting of coffee solely or intercropping with forestry trees are popular methods of growers. We recommend that farmers should intercrop coffee with perennial fruit trees, which creates higher total-income and larger raw biomass.

Keywords: intercropping, Robusta coffee, Siamese cassia, durian, biomass, income.

Introduction

Intercropping is the practice of growing more than one crop in a field at the same times (Lance et al., 2015). Intercropped plants may be cultivated with annual or perennial and follow intercropping principles (Preston, 2003). Intercropping may increase the sustainability of crops, reducing vulnerability to stress of environmental conditions (Stephen, 2000, Lance et al., 2015). There are several ways of intercropping such as in rows, in strips, in mixed ways and in relay (Ann et al., 2018). Arabica coffee (Coffea arabica L.) and Robusta coffee (Coffea canephora Pierre var. Robusta) are mild sun plants (Huynh V. Quoc and Phan V. Tan, 2019) or shade tolerant crops (Da Matta, 2004) that can grow under high canopy trees. Intercropping in Robusta coffee has been used in the process of growing and looking after coffee trees (National Agricultural Extension Center of Vietnam, 2017). Many documents have evaluated the effectiveness of intercropping ways in coffee gardens. Most of these reports mentioned intercropping of coffee trees with annual crops such as corn, beans, cassava, sugarcane, etc. (Helton et al., 2010; Lance et al., 2018; Harelimana et al., 2018). Some reports mentioned intercropping with perennial fruit trees such as banana, coconut, papaya, avocado, durian, macadamia, etc. or timber trees such as Siamese cassia, Leucena, Dalbergia (Margaret, 2008; Helton et al., 2010), none of which assessed biomass, productivity and income yet.

Researches on intercropping of Robusta coffee (Coffea canephora Pierre var. Robusta) with durian and their ability to produce biomass, increase yield and economic efficiency of these models are scarce (Finney et al., 2016). Over the last 10 years, durian, avocado, pepper and macadamia have been intercropped in coffee gardens in the Central Highlands of Vietnam. Among these intercropping models, coffee and durian grow well, save fertilizer and water for irritation, and create higher income, compared with the model of planting sole coffee trees. The trend of growing perennial fruit trees with Robusta coffee is strongly developing in the Central Highlands and many other places in Vietnam. The plantation of coffee growing households in Vietnam is not large, about from 1 to 2 hectares. Intercropping of coffee with perennial fruit trees has brought more ecological efficiency, crop diversity and higher income to their farmers.

The objective of this study is to evaluate the following criteria: 1) ability to provide biomass to soil; 2) yield and income of intercropped coffee and durian. This provides scientific basis for practical recommendation to the farmers.

\section{Results and discussion}

\section{Investment in fertilizer}

All the models have applied fertilizer formula, recommended by the Vietnamese National Agricultural Extension Center (Dave D'haeze, 2017). This regulation determines the amount of organic and inorganic fertilizer for each tree. Therefore, we do not consider this to be a comparative indicator. Fertilizer formula included organic fertilizer and inorganic fertilizer. The organic fertilizer was cow manure 
Table 1. Fertilizer invest for 01 ha season 2018 (only calculating fertilizer cost).

\begin{tabular}{lccccc}
\hline \multirow{2}{*}{ Model } & \multicolumn{3}{c}{ Total volume (kg.ha- ${ }^{-1}$ } & \multicolumn{2}{c}{$\begin{array}{c}\text { Total invest for } \\
\text { fertilizers (USD) }\end{array}$} \\
\cline { 2 - 5 } Sole coffee (control) & manure & $\mathrm{N}$ & $\mathrm{P}$ & $\mathrm{K}$ & 1,431 \\
Coffee with S. cassia & 10,000 & 330 & 100 & 300 & 1,431 \\
Coffee with durian $9 \times 9 \mathrm{~m}$ & 10,000 & 330 & 100 & 300 & 1,604 \\
Coffee with durian $9 \times 6 \mathrm{~m}$ & 10,000 & 374 & 200 & 360 & 1,698 \\
\hline
\end{tabular}

Notes: manure: cow manure; $\mathrm{N}$ : urea pure $46 \%$; $P$ : super phosphate pure $16 \%$; $\mathrm{K}: \mathrm{K}_{2} \mathrm{SO}_{4}$ pure $45 \%$

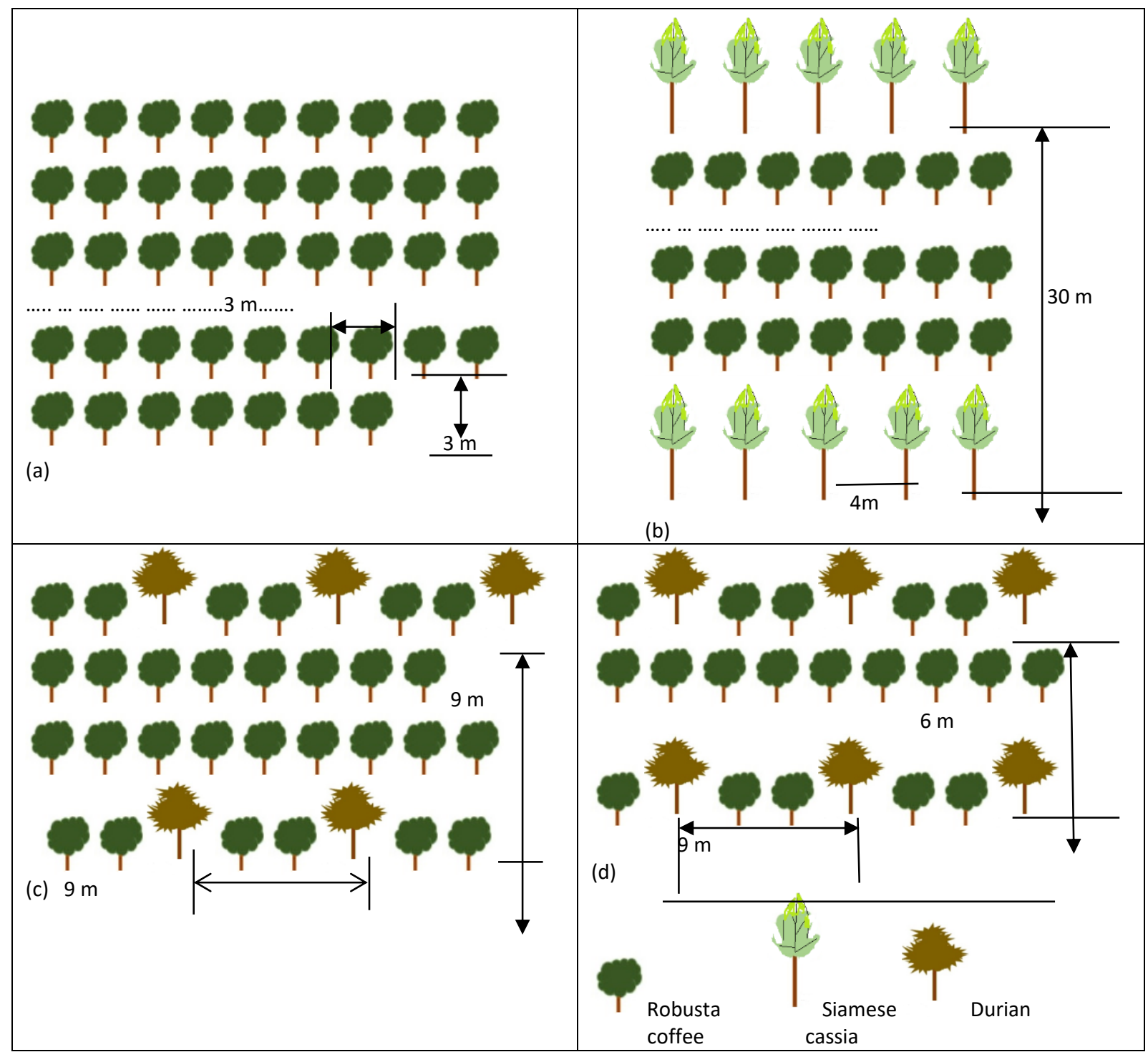

Fig 1. Schematic map: (a) sole coffee; (b) intercrop with Siamese cassia; (c) intercrop with durian $9 \times 9$ m; (d) intercrop with durian 9 $\times 6 \mathrm{~m}$.

Table 2. Tree morphology of intercropping models (12 $\left.{ }^{\text {th }} 2018\right)$.

\begin{tabular}{|c|c|c|c|c|c|}
\hline $\begin{array}{l}\text { Model } \\
\text { Criterion } \\
\end{array}$ & Sole coffee & $\begin{array}{l}\text { Coffee } \\
\text { cassia }\end{array}$ & with & $\begin{array}{l}\text { Coffee with durian } \\
9 \times 9\end{array}$ & $\begin{array}{l}\text { Coffee with durian } 9 \\
\times 6\end{array}$ \\
\hline \multicolumn{6}{|l|}{ High tree $(m)$} \\
\hline Coffee & $1.8^{\mathrm{a}} \pm 0.1$ & $1.8^{\mathrm{a}} \pm 0.1$ & & $1.7^{\mathrm{a}} \pm 0.2$ & $1.9^{\mathrm{a}} \pm 0.2$ \\
\hline Siamese cassia & & $13.5 \pm 1.2$ & & & \\
\hline Durian & & & & $7.0 \pm 0.5$ & $8.0 \pm 0.5$ \\
\hline \multicolumn{6}{|c|}{ Stem diameter $(\mathrm{cm})$} \\
\hline Coffee & $11.5^{\mathrm{a}} \pm 0.4$ & $11^{\mathrm{a}} \pm 0.4$ & & $10.5^{\mathrm{a}} \pm 0.3$ & $9.5^{b} \pm 0.4$ \\
\hline Siamese cassia & & $30 \pm 1.2$ & & & \\
\hline Durian & & & & $28 \pm 0.5$ & $26 \pm 0.4$ \\
\hline \multicolumn{6}{|c|}{ Diameter of canopy (m) } \\
\hline Coffee & $2.6^{\mathrm{a}} \pm 0.2$ & $2.8^{\mathrm{a}} \pm 0.2$ & & $2.7^{\mathrm{a}} \pm 0.3$ & $2.8^{\mathrm{a}} \pm 0.3$ \\
\hline Siamese cassia & & $6.5 \pm 0.5$ & & & \\
\hline Durian & & & & $10.0 \pm 0.4$ & $11.0 \pm 0.4$ \\
\hline
\end{tabular}




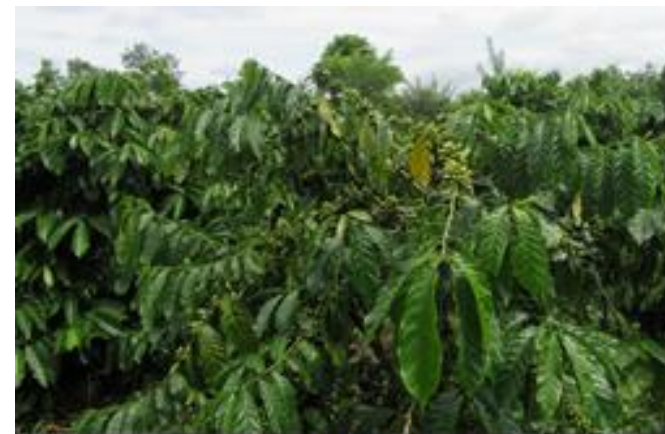

(a) sole coffee

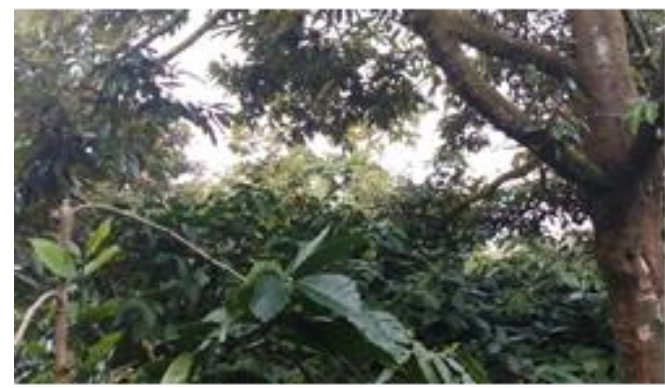

c) intercropping coffee with durian $9 \times 9 \mathrm{~m}$

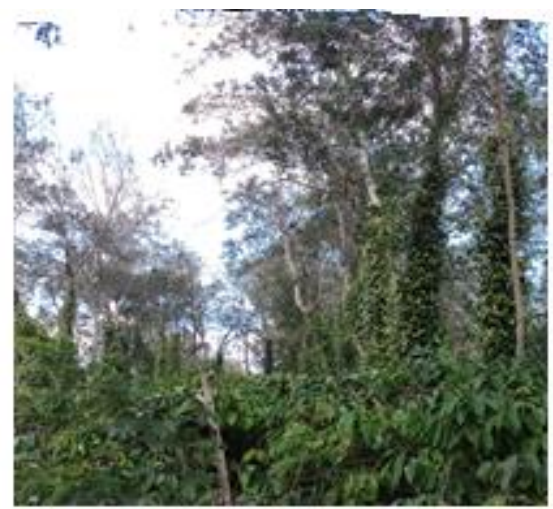

(b) intercropping coffee with Siamese cassia

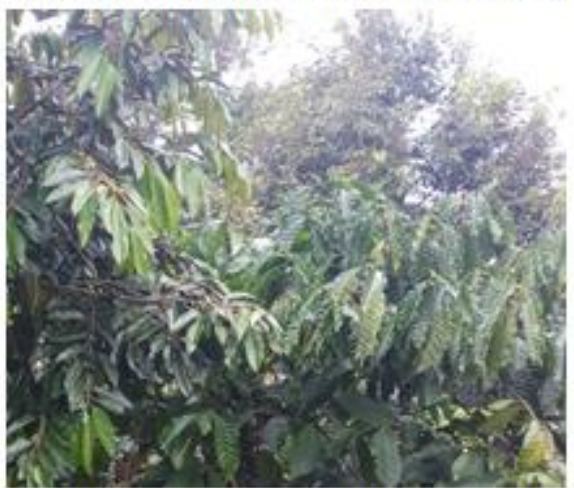

(d) intercropping coffee with durian $9 \times 6 \mathrm{~m}$

Fig 2. Models coffee with Siamese cassia and durian.

Table 3. Raw biomass of models in season 2018 (ton ha $\mathrm{ha}^{-1} \mathrm{y}^{-1}$ ).

\begin{tabular}{|c|c|c|c|c|c|c|}
\hline Model & $\begin{array}{l}\text { Total fallen of } \\
\text { coffee (ton) }\end{array}$ & $\begin{array}{l}\text { Raw coffee } \\
\text { fruits (ton) }\end{array}$ & $\begin{array}{l}\text { Total fallen of } \\
\text { durian (ton) }\end{array}$ & $\begin{array}{l}\text { Raw durian } \\
\text { fruits (ton) }\end{array}$ & $\begin{array}{l}\text { Total fallen of } \\
\text { cassia (ton) }\end{array}$ & $\begin{array}{l}\text { Total biomass } \\
\text { (ton) }\end{array}$ \\
\hline Sole coffee (control) & $54^{\mathrm{a}} \pm 2.3$ & $17.6^{\mathrm{a}} \pm 0.5$ & 0 & 0 & 0 & $71.6^{\mathrm{C}} \pm 1.8$ \\
\hline Coffee with cassia & $54.5^{\mathrm{a}} \pm 1.9$ & $18.1^{\mathrm{a}} \pm 0.3$ & 0 & 0 & $28.8 \pm 1.3$ & $101.4^{b} \pm 3.6$ \\
\hline $\begin{array}{l}\text { Coffee with durian } \\
(9 \times 9 \mathrm{~m})\end{array}$ & $47.5^{b} \pm 1.0$ & $16.2^{\mathrm{a}} \pm 0.3$ & $92.3 \pm 2.1$ & $22.63 \pm 1.5$ & 0 & $178.6^{a} \pm 4.1$ \\
\hline $\begin{array}{l}\text { Coffee with durian } \\
(9 \times 6 \mathrm{~m})\end{array}$ & $39^{c} \pm 1.0$ & $13.6^{b} \pm 0.3$ & $100.5 \pm 1.7$ & $23.32 \pm 1.7$ & 0 & $176.4^{a} \pm 4.5$ \\
\hline $\mathrm{LSD}_{0.05}$ & 4.7 & 2.4 & & & & 3.2 \\
\hline
\end{tabular}

Note: 1 ton $=1000 \mathrm{~kg}$

Table 4. Yield of coffee and durian season $2018\left(\mathrm{~kg} \mathrm{ha}^{-1} \mathrm{y}^{-1}\right)$.

\begin{tabular}{lll}
\hline Model & $\begin{array}{l}\text { Yield of dry bean coffee } \\
\left(\mathrm{kg}^{-1}\right)\end{array}$ & Yield of raw durian $\left(\mathrm{kg} . \mathrm{ha}^{-1}\right)$ \\
\hline Sole coffee (control) & $4,120^{\mathrm{a}} \pm 94.2$ & 0 \\
Coffee with cassia & $4,202^{\mathrm{a}} \pm 86.6$ & 0 \\
Coffee with durian $(9 \times 9 \mathrm{~m})$ & $3,828^{\mathrm{b}} \pm 78.4$ & $22,700^{\mathrm{a}} \pm 645$ \\
Coffee with durian $(9 \times 6 \mathrm{~m})$ & $3,122^{\mathrm{c}} \pm 85.2$ & $23,275^{\mathrm{a}} \pm 812$ \\
LSD $_{0.05}$ & 137.78 & 4,282 \\
\hline
\end{tabular}

Table 5. Income from coffee and durian season 2018 (USD ha ${ }^{-1} \mathrm{y}^{-1}$ ).

\begin{tabular}{|c|c|c|c|}
\hline Model & From coffee & From durian & Total income \\
\hline Sole coffee (control) & $6,060^{a} \pm 139$ & 0 & $6,060^{b} \pm 139$ \\
\hline Coffee with cassia & $6,208^{b} \pm 115$ & 0 & $6,208^{b} \pm 115$ \\
\hline Coffee with durian $(9 \times 9 \mathrm{~m})$ & $5,617^{c} \pm 115$ & 48,913 & $54,530^{\mathrm{a}} \pm 140$ \\
\hline Coffee with durian $(9 \times 6 \mathrm{~m})$ & $4,656^{d} \pm 126$ & 50,869 & $55,525^{\mathrm{a}} \pm 176$ \\
\hline $\mathrm{LSD}_{0.05}$ & 102.61 & & 186.17 \\
\hline
\end{tabular}


$\left(10,000 \mathrm{~kg} \mathrm{ha}^{-1}\right)$, which can improve the soil quality and increase sustainability of gardens. In addition, branches, leaves and fallen fruits of coffee, durian and Siamese cassia were used to make green manure to fertilize the garden. The organic content of the soil was quite high (3.4-3.7\%) and the $\mathrm{pH}$ was slightly low. The amount of inorganic fertilizer ( $N, \mathrm{P}$, $\mathrm{K}$ ) of the intercropping models (Siamese cassia, durian) was not large but there was a balance between $\mathrm{N}, \mathrm{P}$ and $\mathrm{K}$ and the cost of fertilizer was not high, even with the intercropping model with durian (table 1). The amount of fertilizer used was large enough for the coffee and the other trees to grow and develop. The fertilizer, that mainly provides nutrition to coffee and intercropping trees (Siamese cassia or durian) was at a low percentage.

\section{Tree morphology of intercropping models}

Canopy of the models of intercropping in coffee gardens created 2 levels of canopy of leaves: high level from 2 to 6-7 $\mathrm{m}$ (with durian) or from 5 to 12-14 m (with Siamese cassia); low level: from 0.6 to $2 \mathrm{~m}$ (with coffee). This canopy creates the trade-off among ecological elements, suitables for Robusta coffee. High canopy limits the intensity of sunlight down to the coffee canopy. Robusta coffee is a shadetolerant plant (Da Matta, 2004) or mild sun plant (Huynh V. Quoc and Phan V. Tan, 2019). This canopy raised relative humidity, limits wind power and lowered the microclimate temperature of the garden (Quoc and Tan, 2019).

The diameter of canopy of durian trees is quite large (10-11 $\mathrm{m})$. It provides a quite large shade for coffee, when combined with thick canopy layer (from 2 to 6-7 m), especially with the model intercropped with durian $(9 \times 6$ $\mathrm{m})$. The growth and productivity of some coffee trees close to durian was decreased (Table 2).

The stem diameter of all the trees (durian and Siamese cassia) is not too large and does not affect the diameter of the stem of Robusta coffee. The stem of Robusta coffee was order as $9.5-10.5-11-11.5 \mathrm{~cm}$ corresponding to models durian intercrop $9 \times 6 \mathrm{~m}$, durian intercrop $9 \times 9 \mathrm{~m}$, durian intercrop Siamese cassia $30 \times 4 \mathrm{~m}$ and sole coffee, respectively.

\section{Raw biomass of intercropping models}

All raw biomass of the trees include weeds, leaves and fallen fruits of coffee, Siamese cassia and durian were used to make green manure. Farmers buried this biomass into soil 4 times per year. Table 3 shows that the raw biomass of the durian intercropping model is larger than 170 tons ha $^{-1}$ year ${ }^{1}$. It is higher than model of Siamese cassia (101.4 tons ha ${ }^{-1}$ year $^{-1}$ ) and model of the sole coffee. The raw biomass of sole coffee model (including leaves, stems and fallen fruits) is also quite large 71.6 tons $\mathrm{ha}^{-1}$ year $^{-1}$. The difference in raw biomass of intercropping models with durian and Siamese cassia was statistical significant at $P_{0.05}$. The models of intercropping coffee with durian and Siamese cassia provided a large biomass for the soil and contributed to the increase in organic content in the soil. Investment on fertilizers (organic and inorganic) is almost the same, 1.3 USD tree ${ }^{-1}$ (equivalently 1,431 USD ha ${ }^{-1}$ for the sole coffee) for coffee, and $1.57-1.73$ USD tree ${ }^{-1}$ for durian and non for Siamese cassia, but the raw biomass was increased per unit area.

\section{Yield of coffee and durian}

Yield of Robusta coffee in the Central Highlands is very high, from 2.8 to 4.2 tons.ha ${ }^{-1}$ of dry coffee bean per year. Yield of Robusta coffee in Krong Pac district is the highest in the Central Highlands. Yield of coffee in the experimental gardens is quite high in Vietnam and in the world (from 3,100 to $4,200 \mathrm{~kg} \mathrm{ha}^{-1}$ ). Table 4 shows the yield of the models of sole coffee and coffee intercropped with Siamese cassia is a little higher than that of the two models of coffee with durian (from 300 to $1,000 \mathrm{~kg} \mathrm{ha}^{-1}$ ); intercropping model coffee with durian at distance $9 \times 9 \mathrm{~m}$ (T2), which reduced productivity by $300 \mathrm{~kg}$ compared to sole coffee. If durian trees are planted at a close distance $9 \times 6 \mathrm{~m}$ (T3), the coffee yield will decrease (reduce by $1,000 \mathrm{~kg} \mathrm{ha}^{-1}$ ).

Yield of durian in the two models was quite high (22.7 23.27 tons $\mathrm{ha}^{-1}$ ). The coffee model intercropped with durian at distance $9 \times 6 \mathrm{~m}$ showed a yield increased of $575 \mathrm{~kg} \mathrm{ha}^{-1}$, in spite of increased number of durian trees ha ${ }^{-1}$ (add 62 trees.ha $\left.{ }^{-1}\right)$. Intercropping of coffee with durian at closer spacing $(9 \times 6 \mathrm{~m})$ reduced the yield of each coffee and durian. The difference yield of coffee and durian was statistical significant at $\mathrm{P}_{0.05}$.

\section{Income from coffee and durian}

Our results showed that the income from coffee is not high, while durian produced very high income value. Income from intercropping of coffee with durian is approximately equal to that from sole durian. Statistical analysis showed income of sole coffee and coffee with Siam cassia is not different but has difference with coffee with durian $9 \times 9 \mathrm{~m}$ and coffee with durian $9 \times 6 \mathrm{~m}$ (table 5). This is the most important source of income for farmers. Each household has only 1 to 2.0 ha of land in the studied area. The above income is big enough to cover their expenses.

Intercropping Robusta coffee with durian has significantly increased raw biomass. In addition to ecological balance for microclimate, raw biomass is a valuable source for green manure. Yield of Robusta coffee intercropped with durian has decreased but not much (reduce $300-1000 \mathrm{~kg} \mathrm{ha}^{-1}$ year ${ }^{1}$ ), but produced considerable yield of durian (increase 22.723.27 tons. ha $^{-1}$.year ${ }^{-1}$ ). Income from the model Robusta with durian has increased significantly from 6,000-6,200 USD to $54,500-55,500$ USD ha ${ }^{-1}$ year $^{-1}$. But the model of Robusta coffee with durian at space $9 \times 6 \mathrm{~m}$ did not increase yield and income of coffee. The durian is a fruit tree with high economic value, increasing significant income to farmers. The soil and climate of Krong Pac district are suitable for Robusta coffee and durian. The intercropping model of Robusta coffee with durian at space $9 \times 9 \mathrm{~m}$ can be developed.

\section{Materials and methods}

\section{Plant material}

The experiments were conducted on Robusta coffee (Coffea canephora Pierre var. Robusta), TR8 variety, planted in 2000 (18 years old), space between the trees was $3 \times 3 \mathrm{~m}$, equivalent 1100 tree ha $^{-1}$; Siamese cassia (Cassia siamea Lam.) planted in 2000, space between the trees was $4 \times 30$ $\mathrm{m}$, equivalent 85 trees. ha $^{-1}$; durian (Durio zibethinus Murr.) Monthong variety, planted in 2010 (8 years old), have 2 
spaces between the trees is $9 \times 9 \mathrm{~m}$ equivalent 100 trees ha $^{-1}$ and $9 \times 6$ m equivalent 162 trees.ha ${ }^{-1}$.

\section{Experimental location}

The 4 models, each model is 1 ha, $200 \mathrm{~m}$ apart at Ea Yong commune, Krong Pac district, Daklak province, Vietnam; $12^{\circ} 72^{\prime} 27^{\prime \prime} \mathrm{N}$ and $108^{\circ} 27^{\prime} 59^{\prime \prime} \mathrm{E}$. Soil is Rhodic Ferralsol; slopes: 3-5 ${ }^{\circ}$, soil horizon $>1.0 \mathrm{~m}$.

Soil samples were collected from $0-30 \mathrm{~cm}$ layer. The samples were sent to the Laboratory of Tay Nguyen Biotechnological and Environmental Institute for the chemical analysis and the results were as follows: $\mathrm{pH} 4.6-4.8$; OM 3.4-3.7\%; total $\mathrm{N}$ 0.19-0.21\%; available $\mathrm{P} 7.5-7.8 \mathrm{mg} .100 \mathrm{~g}^{-1}$ of soil; available $\mathrm{K}$ $14-16 \mathrm{mg} .100 \mathrm{~g}^{-1}$ of soil; exchangeable Ca $2.8-2.9 \mathrm{mg} .100 \mathrm{~g}^{-1}$ of soil and exchangeable Mg 2.1-2.2 mg.100 $\mathrm{g}^{-1}$ of soil.

Krong Pac district is in the tropical highland climate with an average temperature of $24^{\circ} \mathrm{C}$; average precipitation 1850 $\mathrm{mm}$ year $^{-1}$; dry season 6 months (from November to April) and rainy season 6 months per year (from May to October); average relative humidity of $(\mathrm{RH}) 81 \%$; altitude $550 \mathrm{~m}$; average number of hours of sunshine.year ${ }^{-1} 2.500$.

\section{Experiment duration}

Totally 19 months (from $10^{\text {th }} 2017$ to $4^{\text {th }} 2019$ ).

Experimental design: The experiment was performed in $4 \mathrm{x}$ 3 factorial randomized complete block design with four models. The first model (T0-control) is sole coffee, at space of $3 \times 3 \mathrm{~m}$, without high-shading trees. The second model (T1) was coffee with Siamese cassia, at space of $3 \times 3 \mathrm{~m}$ for coffee trees, and $4 \times 30 \mathrm{~m}$ for Siamese cassia trees (ratio: 10 rows of coffee and 1 row of Siamese cassia). The third model (T2) was coffee with durian, space of coffee is $3 \times 3 \mathrm{~m}$ and of durian is $9 \times 9 \mathrm{~m}$ (ratio: 3 rows of coffee and 1 row of durian). The fourth model (T3) was coffee with durian, space of coffee is $3 \times 3 \mathrm{~m}$ and of durian is $9 \times 6 \mathrm{~m}$ (ratio: 3 rows of coffee and 1 row of durian). The basal trial was $1000 \mathrm{~m}^{2}$ and it was repeated 3 times (Fig 1).

Traits measured: Annual biomass including raw yield of shoots, leaves, flowers, fruits falling off trees (coffee, durian and Siamese cassia), and fruit yield of coffee and durian. Each trial has 3 frames made of plastic fiber, with a size of 9 x $9 \mathrm{~m}$, to obtain raw biomass falling per week. The majority of raw biomass was mainly due to cutting and pruning, periodically 4 times year $^{-1}$. The raw biomass from fruits (coffee and durian) was collected many times, resulting in total harvests. The annual yield is the total volume of fruit harvests (from coffee and durian). The coffee yield is the volume of dry coffee beans with humidity of $13 \%$; the yield of durian is raw fruit.

Annual income is the selling price multiplied by the yield of coffee beans and durian fruit (VND-Vietnam dong) then converted into USD at the exchange rate of Vietnam.

The data was processed by EXCEL software and the means was separated by Turkey's post-hoc and Duncan's test at P $<0.05$.

\section{Conclusions}

Investment on fertilizers for coffee and durian was not much higher than that for sole coffee. The structure of canopy in the garden intercropped with Siamese cassia and durian at space $9 \times 9 \mathrm{~m}$ did not affect the growth and yield of Robusta coffee. The Siamese cassia and durian significantly increased raw biomass, which was used to produce green manure. The model T2 intercrop of coffee with durian $(9 \times 9 \mathrm{~m})$ reduced the yield of dry coffee bean by $300 \mathrm{~kg} \cdot \mathrm{ha}^{-1}$ and the model T3 intercrop of coffee with durian $(9 \times 6 \mathrm{~m})$ reduced coffee yield by $1000 \mathrm{~kg} . \mathrm{ha}^{-1}$ compared with sole coffee garden $(4,120$ kg.ha $\left.{ }^{-1}\right)$. However, these models produced between 22 tons and 23 tons of durian raw fruits.ha ${ }^{-1}$, which brought about high income for farmers.

\section{Acknowledgments}

We are thankful to Nguyen Van Thuong and Phan Van Ha, at Ea Yong commune, Krong Pac district, Daklak province for helping us to carry out the intercropping models.

\section{References}

Ann Bybee, Finley K, Matthew RR (2018) Review: Advancing intercropping research and practices in industrialized agricultural landscapes. Agriculture-London. 8 (80): 1-24.

Da Matta FM (2004) Ecophysiological constraints on the production of shade and unshaded coffee: a review. Field Crop Res. 86 (2): 99-114.

Dave D'haeze (ed.) (2017) Good agricultural practices for robusta coffee production. National agricultural extension center (in Ministry of Agriculture and Rural Development of Vietnam).

Finney DM, White CM, Kaye JP (2016) Biomass production and carbon/nitrogen ratio influence ecosystem services from cover crop mixtures. Agron J. 108 (1): 39-52.

Lance WR, Polly JE, Sabrina C, Jeffrey SW (2015) Sustainable intensification in dry lands: What resilience and vulnerability can tell us. Agr Syst. 135: 133-140.

Harelimana A, Le Goff G, Ntirushwa Rukazambuga DT and Hance T (2018) Coffee production systems: Evaluation of intercropping system in coffee plantations in Rwanda. J Agr Sci. 10 (9): 17-28.

Helton NS, Irene MC, Jose MF, Flavia CPG, Veronica RB, Alvori CS Anor FC, and Eduardo SM (2010) Selection of native trees for intercropping with coffee in the Atlantic Rainforest biome. Agroforest Syst. 80 (1): 1-16.

Margaret W. Mithamo (2008) Effect of intercropping coffee with fruit trees on coffee eco-physiological and soil factors at coffee research foundation in Ruiru, Kiambu county, Kenya. Paper presented at BSc environmental science of Kenyatta Uni.

Preston Sullivan (2003) Intercropping principles and production practices. ATTRA: Approve technology transfer for rural areas, 84-92.

Stephen R Gliessman (2000) Agroecosystem diversity and Stability. In: Agroecology-Ecologycal processes in sustainable agriculture, 1st edn. Lewis, USA, 227-248.

Quoc and Tan (2019) Evaluating the change of some ecological factors in coffee canephora farm intercropping perennial plants in dry season at Daklak province. Taynguyen J Sci. 35, p.41-46. 